UDC: 575.224 .2$]: 618.19-006.6+616-006.446$

\title{
The polymorphisms of genes involved in DNA methylation in patients with malignancies from West Ukraine
}

\author{
I. M. Dmytruk ${ }^{1}$, H. V. Makukh ${ }^{1}$, M. Y. Thyrkus ${ }^{1}$, N. I. Kitsera ${ }^{1}$ \\ ${ }^{1}$ State Institution «Institute of Hereditary Pathology, NAMS of Ukraine» \\ 31a, M. Lysenko Str., Lviv, Ukraine, 79008 \\ irynamdmytruk@gmail.com
}

\begin{abstract}
Aim. To determine a potential role of single-nucleotide polymorphisms in genes involved in DNA methylation (MTHFR, MTR, TYMS) in the breast cancer risk and risk of leukemia in a case-control study from West Ukraine. Methods. Genotyping of MTHFR $677 C>T$, MTR $2756 A>G$ and $T S 3 R 2 R, T S 3 R G>C$ was performed in 60 patients with leukemia, 90 patients with breast cancer and in 100 persons from a control group. The molecular-genetic analysis was performed by Polymerase Chain Reaction and Restriction Fragment Length Polymorphism analysis. A statistical analysis was conducted by Chi-square tests and odds ratio (OR) calculation. Results. We did not observe any significant difference in genotype frequencies of the MTHFR and TYMS polymorphisms between the patients and the controls. The MTR $2756 \mathrm{AA}$ genotype frequency was significantly higher in the breast cancer patients vs. control $(0.67 v s .0 .50, \mathrm{p}=0.02)$ while the difference between the leukemia patients and the control group was not statistically significant. The increased risk of breast cancer development was associated with the MTR $2756 \mathrm{AA}$ genotype $(\mathrm{OR}=2.00, \mathrm{CI}-95 \%: 1.11-3.60)$ and the MTR $2756 \mathrm{~A}$ allele (OR $=1.75, \mathrm{CI}-95 \%: 1.08-2.84)$. Conclusions. Our findings show that West Ukrainian inhabitants carrying at least one MTR $2756 \mathrm{~A}$ allele have a significantly increased risk of breast cancer.
\end{abstract}

Ke y w or d s: methylation, polymorphism, gene, leukemia, breast cancer

\section{Introduction}

Aberrant DNA methylation is a key epigenetic factor in tumorogenesis [1]. The genomic methylation patterns depend of the one-carbon metabolizing enzymes, that involved in the provision of methyl groups, and DNA methyltransferases (DNMT) that transfer methyl groups from S-adenosylmethionine to DNA CpG dinucleotides [2, 3].

A crucial role for the control on DNA methylation as well as DNA synthesis and repair mechanisms belongs to the provision of adequate pools of methyl groups through the functional activity of methylenetetrahydrofolate reductase (MTHFR), methionine synthase (MTR) and thymidylate synthase (TYMS) in one-carbon metabolism. MTHFR catalyzes the ir- reversible conversion of 5,10 - methylen-tetrahydrofolate (THF) to 5-methyl-THF. The 5,10-methyleneTHF is used by TYMS in the methylation of dUMP to dTMP, which is the only de novo source of thymidine required for DNA synthesis and repair. The 5-methylTHF is a methyl group donor for the remethylation of homocysteine to methionine catalysed by MTR [4].

The genetic variants of MTHFR, MTR, and TYMS have been shown to affect the function of corresponding proteins [5-8]. A single nucleotide polymorphism $677 C>T$ of the MTHFR gene is correlated with the enzyme thermolability and reduced activity [6]. A common polymorphism $2756 A>G$ in the $M T R$ gene is associated with a lower enzyme activity, causing DNA hypomethylation [7]. The individuals with polymorphisms in the TYMS 5 untranslated enhanc-

(C) 2016 I. Dmytruk et al.; Published by the Institute of Molecular Biology and Genetics, NAS of Ukraine on behalf of Biopolymers and Cell. This is an Open Access article distributed under the terms of the Creative Commons Attribution License (http://creativecommons.org/licenses/by/4.0/), which permits unrestricted reuse, distribution, and reproduction in any medium, provided the original work is properly cited 
er region (TSER), that contains a 28-bp tandem repeat sequence, and those carrying alleles with three repeats (3R) have higher TYMS mRNA levels than the individuals with two repeats (2R) [9]. An additional polymorphism mapping to the second repeat sequence of the $3 \mathrm{R}$ allele, $3 R G>C$, may also affect the TYMS expression, $3 R C$ alleles being associated with a comparable expression to $2 R$ alleles [10]. There are a large number of molecular epidemiological studies about a role of the folate metabolic enzyme gene polymorphism in different kinds of malignancy: lung cancer [11], breast cancer [12-15], lymphoma $[16,17]$. However, the association between polymorphism and cancer risk is still controversial.

It is well known that methylation of the promoter and exon regions is one of the major regulatory mechanisms of gene expression; thus, we hypothesized that a gene involved in the folate metabolism may be responsible for regulating the methylation status of other genes associated with cancer risk. Therefore, the aim of this study was to determine the occurrence of single-nucleotide polymorphisms in the genes encoding the folate metabolizing enzymes (MTHFR, MTR, TYMS) in a case-control study from West Ukraine for their potential role in the breast cancer risk and risk of leukemia.

\section{Materials and Methods}

Patients. For molecular genetic testing the DNA samples, that were obtained from the venous blood nuclear cells of the patients with cancer, were used. The patients were hospitalized in the Regional Specialized Children's Hospital, Lviv Regional Specialized Oncological Clinic and Lviv regional hospital. To form the patient groups a detailed medical anamnesis was obtained and clinical pictures of the oncological disease were estimated. The data were analyzed among 150 patients, who were separated into 2 groups in accordance with their diagnosis. The first research group contains 60 patients with leukemia and lymphoma (65\% - boys, $35 \%$ girls) aged 2 to 16 years. The diagnosis of oncohematological pathology was established for the first time. The group includes the 17 patients with acute leukemia, 22 persons with Hodgkin's lymphoma and 21 patients with non-Hodgkin's lymphoma. 90 patients with breast cancer compose the second research group: women with breast cancer (II IV stages) aged 35 to 75 years with burdened family history of breast or ovarian cancer. The control group consist of 100 healthy patients without cancer pathology in anamnesis. All persons from the research and control groups were from West Ukraine.

All patients signed the informed consent for using their DNA samples for molecular-genetic testing. The experimental protocol was approved by the Bioethics Committee of SI "Institute of hereditary pathology NAMS of Ukraine" and complied with international standards.

Genotyping. The extraction and refinement of DNA from the leukocytes of the peripheral blood were conducted according to the salting-out protocol extraction [18]. The amplification of DNA chain in vitro was performed using the method of polymerase chain reaction (PCR) $[11,12]$. To detect the variable number tandem repeats (VNTR) for the TYMS gene, PCR product was separated on a $2 \%$ agarose gel (Fig.1). The samples showing the $2 R / 3 R$ or $3 R / 3 R$ genotypes were further analyzed for the $3 R G>C$ polymorphism by the method of restriction fragment length polymorphism (RFLP) using HaelII restriction enzyme (Fig.2).

Genotyping of the MTHFR $677 C>T$ and MTR $2756 A>G$ polymorphisms was performed by RFLP using the restriction enzymes HinfI and HaeIII respectively. The obtained restriction fragment was detected by $2 \%$ agarose gels electrophoresis.

Statistics. The results were processed with the methods of variation statistics suitable for the biological studies and recommended for processing the molecular genetic research results: Chi-square analysis ( $\chi 2$ tests), Hardy - Weinberg equilibrium, odds ratio (OR) with $95 \%$ confidence interval (CI).

\section{Results and Discussion}

There are many data on the interrelation between polymorphisms of the gene involved in the methylation process and the cancer susceptibility but the results vary depending of the patient ethnicity. 


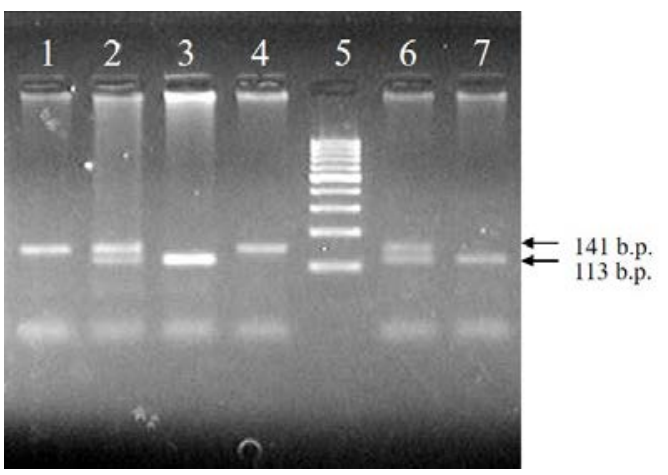

Fig. 1. Molecular genetic analysis of TYMS 3R/2R VNTR polymorphism, $2 \%$ agarose gel. Lane 1,4 - genotype 3R3R; lane 2, 6 - genotype 3R2R; lane 3, 7 - genotype 2R2R; lane 5-Marker pUC19 DNA/MspI.

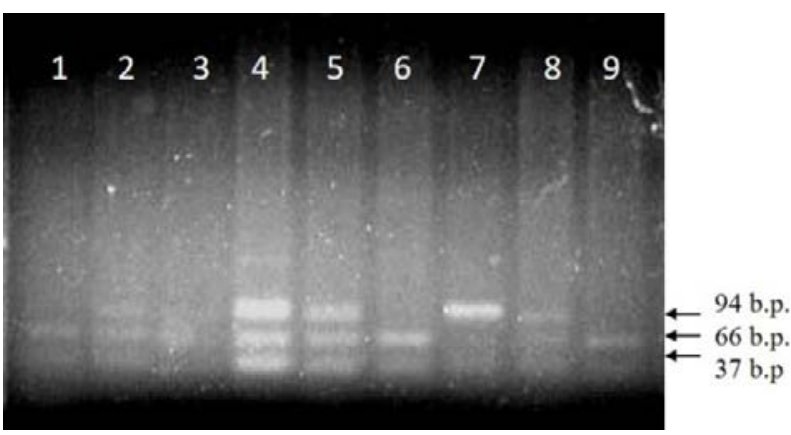

Fig. 2. Restriction analysis of TYMS $3 \mathrm{R} \mathrm{G}>\mathrm{C}$ polymorphism, 4 $\%$ agarose gel. Lane 1, 6, 9 - genotype GG; lane 2, 3, 4, 5, 8 genotype GC; lane 7 - genotype CC.

Table 1. Genotypes and alelles frequency of $M T H F R$ 677C $>T$, MTR $2756 A>G$ and $T Y M S 3 R 2 R, 3 R G>C$ polymorphisms among patients with different types of cancer and control group.

\begin{tabular}{|c|c|c|c|c|c|c|c|c|c|c|c|c|c|c|c|}
\hline \multirow[b]{3}{*}{$\begin{array}{l}\text { Genotype/ } \\
\text { allele }\end{array}$} & \multicolumn{15}{|c|}{ Frequency of genotypes and alelles, $\%$} \\
\hline & \multicolumn{5}{|c|}{ Patients with breast cancer } & \multicolumn{5}{|c|}{ Patients with leukemia } & \multicolumn{5}{|c|}{ Group of control } \\
\hline & $N$ & 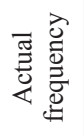 & 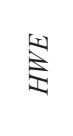 & $\chi^{2}$ & $\mathrm{P}$ & $N$ & 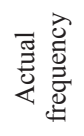 & $\stackrel{1}{\vdots}$ & $\chi^{2}$ & $\mathrm{P}$ & $N$ & 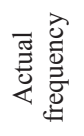 & $\stackrel{5}{\vdots}$ & $\chi^{2}$ & $\mathrm{P}$ \\
\hline \multicolumn{16}{|c|}{ MTHFR $677 C>T$} \\
\hline $677 \mathrm{CT}$ & 42 & 47 & 42.9 & \multirow{4}{*}{0.71} & \multirow{4}{*}{0.40} & 24 & 40 & 39.1 & \multirow{4}{*}{0.03} & \multirow{4}{*}{0.86} & 52 & 52 & 44.9 & \multirow{4}{*}{2.52} & \multirow{4}{*}{0.11} \\
\hline $677 \mathrm{TT}$ & 7 & 7 & 9.7 & & & 4 & 7 & 7.1 & & & 8 & 8 & 11.6 & & \\
\hline $677 \mathrm{C}$ & 124 & 69 & - & & & 88 & 73 & - & & & 132 & 66 & - & & \\
\hline $677 \mathrm{~T}$ & 56 & 31 & - & & & 32 & 27 & - & & & 68 & 34 & - & & \\
\hline $2756 \mathrm{GG}$ & 4 & 4 & 3.6 & \multirow[t]{3}{*}{0.29} & \multirow[t]{3}{*}{0.59} & 3 & 5 & 4.7 & \multirow[t]{3}{*}{0.02} & \multirow[t]{3}{*}{0.89} & 8 & 8 & 8.4 & \multirow[t]{3}{*}{0.04} & \multirow[t]{3}{*}{0.84} \\
\hline $2756 \mathrm{~A}$ & 146 & 81 & - & & & 94 & 78 & - & & & 142 & 71 & - & & \\
\hline $2756 \mathrm{G}$ & 34 & 19 & - & & & 26 & 22 & - & & & 58 & 29 & - & & \\
\hline \multicolumn{16}{|c|}{$T Y M S 3 R 2 R, 3 R G>C$} \\
\hline $\mathrm{HH}$ & 1 & 1 & 2.1 & \multirow{4}{*}{0.56} & \multirow{4}{*}{0.45} & 1 & 2 & 2.3 & \multirow{4}{*}{0.13} & \multirow{4}{*}{0.72} & 0 & 0 & 2.0 & \multirow{4}{*}{2.65} & \multirow{4}{*}{0.1} \\
\hline $\mathrm{HL}$ & 24 & 27 & 24.7 & & & 16 & 27 & 25.5 & & & 28 & 28 & 24.1 & & \\
\hline LL & 65 & 72 & 73.2 & & & 43 & 71 & 72.3 & & & 72 & 72 & 74.0 & & \\
\hline $\mathrm{H}$ & 26 & 14 & - & & & 18 & 15 & - & & & 28 & 14 & - & & \\
\hline
\end{tabular}

Note: $N$ - quantity of observation; HWE (Hardy-Weinberg equilibrium) - theoretically expected frequency; *p $>0.05-$ frequency distribution of genotypes conformed to the HWE; High (H) and low (L) TS expression genotypes based on TSER and TSER 3R G>C polymorphisms (high: $3 R G / 3 R G, 3 R G / 3 R C, 3 R G / 2 R$; low: $3 R C / 3 R C, 3 R C / 2 R, 2 R / 2 R$ ); HH - 3RG3RG genotype; HL - 3RG2R, $3 R G 3 R C$ genotypes; $L L-2 R 2 R, 3 R C 2 R$, 3RC3RC genotypes. 
In this study we analyse functional polymorphisms in the genes encoding the one-carbon metabolism enzymes and compare it with other population study. We carried out the molecular genetic testing of the genotype and allele frequency of the MTHFR $677 C>T$, MTR $2756 A>G$ and TYMS $2 R / 3 R$, TYMS $3 R G>C$ polymorphisms among the patients with breast cancer, leukemia and of a control group. The established genotypes and alleles distribution of testing polymorphic loci in the research and control groups did not significantly differ from the theoretically expected frequency conformed to Hardy-Weinberg equilibrium (Table 1). We have determined and compared the alleles and genotypes frequency of the studied polymorphic loci in the control and case groups (Table 2).
The genotypes and allele distribution of the MTHFR $677 C>T$ polymorphic loci did not show significant difference between the case and control groups. (Table 2.). The frequency of low-expression 677 TT genotype was $8 \%$ in the group of breast cancer and $7 \%$ in the control group as much as in the group of patients with leukemia. The frequency of $677 T$ allele did not differ in the case groups compared to the control $(34 \%, 27 \%$ vs. $31 \%)$. OR calculation also did not show statistically significant result (Table 2). Our findings coincide with the results of German and Korean researches [19, 20]. The decreased susceptibility to acute lymphoblastic leukaemia was found in the West European populations [21]. It was found that the $677 C>T$ polymorphism is strongly associated with breast cancer in the East

Table 2. Genotypes and alelles distribution of MTHFR 677C > T, MTR 2756 A>G, DNMT3B -149C > T, DNMT3B -579 G>T and TYMS 3R2R, 3R G>C polymorphisms among the patients with different types of cancer compared to the control group

\begin{tabular}{|c|c|c|c|c|c|c|c|c|c|}
\hline \multirow{2}{*}{$\begin{array}{l}\text { Genotype/ } \\
\text { allele }\end{array}$} & \multirow{2}{*}{$\begin{array}{c}\begin{array}{c}\text { Group of } \\
\text { control }(\mathrm{n}=100)\end{array} \\
\mathrm{n}(\%)\end{array}$} & \multicolumn{4}{|c|}{$\begin{array}{l}\text { Patients with breast cancer } \\
\qquad(\mathrm{n}=90)\end{array}$} & \multicolumn{4}{|c|}{$\begin{array}{l}\text { Patients with leukemia } \\
\qquad(\mathrm{n}=60)\end{array}$} \\
\hline & & $\mathrm{n}(\%)$ & $\chi^{2}$ & $\mathrm{P}$ & OR $(95 \%$ CI $)$ & n ( \%) & $\chi^{2}$ & $\mathrm{p}$ & OR $(95 \% \mathrm{CI})$ \\
\hline $677 \mathrm{CC}$ & $40(40)$ & $41(46)$ & \multirow[b]{2}{*}{0.41} & \multirow[b]{2}{*}{0.52} & $1.26(0.71-2.23)$ & $32(53)$ & \multirow[b]{2}{*}{2.10} & \multirow[b]{2}{*}{0.15} & $1.71(0.90-3.27)$ \\
\hline 677CT & $52(52)$ & $42(47)$ & & & $0.81(0.46-1.43)$ & $24(40)$ & & & $0.62(0.32-1.18)$ \\
\hline $677 \mathrm{C}$ & $132(66)$ & 124 (69) & \multirow{2}{*}{0.36} & \multirow{2}{*}{0.55} & $1.14(0.74-1.75)$ & $88(73)$ & \multirow{2}{*}{1,88} & \multirow{2}{*}{0,17} & $1.42(0.86-2.33)$ \\
\hline $677 \mathrm{~T}$ & $68(34)$ & $56(31)$ & & & $0.88(0.57-1.35)$ & $32(27)$ & & & $0.71(0.43-1.16)$ \\
\hline \multicolumn{10}{|c|}{$M T R 2756 \mathrm{~A}>\mathrm{G}$} \\
\hline $2756 \mathrm{AA}$ & $50(50)$ & $60(67)$ & 5.15 & $0.02 *$ & $\mathbf{2 . 0 0} *(1.11-3.60)$ & $37(62)$ & 2.09 & 0.15 & $1.61(0.84-3.09)$ \\
\hline $2756 \mathrm{G}$ & $58(29)$ & $34(19)$ & 5.28 & $0.02 *$ & $0.57(0.35-0.92)$ & $26(22)$ & 2.08 & 0.15 & $0.68(0.40-1.15)$ \\
\hline \multicolumn{10}{|c|}{$T Y M S 3 R 2 R, 3 R G>C$} \\
\hline $\mathrm{H} / \mathrm{H}$ & $1(1)$ & $1(1)$ & \multirow{3}{*}{0.26} & \multirow{3}{*}{0.88} & $1.11(0.07-18.05)$ & $1(2)$ & \multirow{3}{*}{0.32} & \multirow{3}{*}{0.85} & $1.68(0.10-27.33)$ \\
\hline $\mathrm{H} / \mathrm{L}$ & $30(30)$ & $24(27)$ & & & $0.85(0.45-1.60)$ & $16(27)$ & & & $0.85(0.42-1.73)$ \\
\hline $\mathrm{L} / \mathrm{L}$ & $69(69)$ & $65(72)$ & & & $1.17(0.62-2.19)$ & $43(71)$ & & & $1.14(0.56-2.30)$ \\
\hline $\mathrm{H}$ & $32(16)$ & $26(14)$ & \multirow{2}{*}{0.18} & \multirow{2}{*}{0.67} & $0.89(0.51-1.55)$ & $18(15)$ & \multirow{2}{*}{0.06} & \multirow{2}{*}{0.81} & $0.92(0.49-1.75)$ \\
\hline $\mathrm{L}$ & $168(84)$ & $154(86)$ & & & $1.13(0.64-1.98)$ & $102(85)$ & & & $1.08(0.57-2.06)$ \\
\hline
\end{tabular}

Note: $n$ - quantity of observation; * $\mathbf{p}<\mathbf{0 . 0 5}$ - statistically significant difference; $\mathbf{O R}$ * statistically significant association between genotype and alleles polymorphism and cancer susceptibility; High (H) and low (L) TS expression genotypes based on TSER and TSER $3 R G>C$ polymorphisms (high: $3 R G / 3 R G, 3 R G / 3 R C, 3 R G / 2 R ;$ low: $3 R C / 3 R C, 3 R C / 2 R, 2 R / 2 R$ ); HH - 3RG3RG genotype; $H L-3 R G 2 R$, 3RG3RC genotypes; $L L-2 R 2 R$, 3RC2R, 3RC3RC genotypes 
The polymorphisms of genes involved in DNA methylation in patients with malignancies from West Ukraine

Table 3. Genotype and allele frequency of the TYMS 3R2R, 3R G>C polymorphisms among the patients with different types of cancer and the control group

\begin{tabular}{|c|c|c|c|c|c|c|c|}
\hline \multicolumn{2}{|c|}{$\begin{array}{l}T Y M S 3 R 2 R, \\
\quad 3 R G>C\end{array}$} & \multicolumn{2}{|c|}{$\begin{array}{l}\text { Group of control } \\
(\mathrm{N}=100) \\
\mathrm{n}(\%)\end{array}$} & \multicolumn{2}{|c|}{$\begin{array}{l}\text { Patients with breast cancer } \\
(\mathrm{N}=90) \\
\mathrm{n}(\%)\end{array}$} & \multicolumn{2}{|c|}{$\begin{array}{l}\text { Patients with leukemia } \\
(\mathrm{N}=60) \\
\mathrm{n}(\%)\end{array}$} \\
\hline \multicolumn{8}{|l|}{ Genotypes } \\
\hline \multirow{3}{*}{ 3R3R } & 3RG3RG & & $1(1)$ & & $1(1)$ & & $1(2)$ \\
\hline & 3RG3RC & $27(27)$ & $17(17)$ & $26(29)$ & $14(16)$ & $14(23)$ & $8(13)$ \\
\hline & 3RC3RC & & $9(9)$ & & $11(12)$ & & $5(8)$ \\
\hline \multirow{2}{*}{$3 R 2 R$} & $2 \mathrm{R} 3 \mathrm{RG}$ & $40(40)$ & $13(13)$ & $43(48)$ & $10(11)$ & $20(48)$ & $8(13)$ \\
\hline & $2 \mathrm{R} 3 \mathrm{RC}$ & $40(40)$ & $27(27)$ & $45(40)$ & $33(37)$ & $29(40)$ & $21(35)$ \\
\hline \multicolumn{2}{|c|}{$2 \mathrm{R} 2 \mathrm{R}$} & \multicolumn{2}{|c|}{$33(33)$} & \multicolumn{2}{|c|}{$21(23)$} & \multicolumn{2}{|c|}{$17(29)$} \\
\hline \multicolumn{8}{|l|}{ Alelle } \\
\hline \multirow{2}{*}{$3 \mathrm{R}$} & $3 R G$ & \multirow{2}{*}{$94(47)$} & $32(16)$ & \multirow{2}{*}{$95(53)$} & $26(15)$ & \multirow{2}{*}{$57(48)$} & $18(15)$ \\
\hline & $3 \mathrm{RC}$ & & $62(31)$ & & $69(38)$ & & $39(33)$ \\
\hline \multicolumn{2}{|c|}{$2 \mathrm{R}$} & \multicolumn{2}{|c|}{$106(53)$} & \multicolumn{2}{|c|}{$85(47)$} & \multicolumn{2}{|c|}{$63(52)$} \\
\hline
\end{tabular}

Note: $N$ - quantity of observation

Asian populations [22]. Therefore, our results seem to be more relevant to other population studies: the lack of association of the MTHFR polymorphisms with the breast cancer risk was observed in Indian women [23] and in the residents of Scotland [13], Finland [24] and Greece [25].

For better understanding of the clinical significance of the SNP and VNTR of TYMS, we analysed the frequency of comprehensive genotypes of $3 R 2 R$ and $3 R$ $G>C$ polymorphisms in case and control groups. The allele and genotype frequency is summarized in Table 3.

The TYMS genotypes were each stratify into three groups because the statistical power was insufficient by analysis with more than three genotype groups. The TYMS functional groups were classified into the $\mathrm{H}$-group $(\mathrm{H} / \mathrm{H}$ and $\mathrm{H} / \mathrm{L})$ and L-group $(\mathrm{L} / \mathrm{L})$. The TYMS $3 G$ allele was considered a high-expression allele and $2 R$ or $3 R C$ as low-expression alleles according to the in vitro functional analysis [26]. Therefore, the TS genotypes of $2 \mathrm{R} / 3 \mathrm{G}, 3 \mathrm{C} / 3 \mathrm{G}$, or $3 \mathrm{G} / 3 \mathrm{G}$ were considered as high expression $(\mathrm{H})$ type and $2 \mathrm{R} / 2 \mathrm{R}$, $2 \mathrm{R} / 3 \mathrm{C}$ or $3 \mathrm{C} / 3 \mathrm{C}-$ low expression (L) type. According to our results, there was no significant association between the genotype groups and cancer pathology (Table 2.). Thus, the frequency of $\mathrm{H}$-genotype group amounts $15 \%$ in the patients with leukemia, $14 \%$ in the control group and the same in the patients with breast cancer. The following frequencies were detected in the L-genotype functional group: $85 \%, 86 \%$ and $86 \%$ for the patients with leukemia, breast cancer and control group respectively.

Our results are very similar to those reported for the Spanish [27] and Mexican [28] women. The studies on other populations have found the significant associations between the TYMS gene TSER variations and breast cancer development [14]. For the TYMS 2R3R polymorphisms was found a decreased susceptibility to acute lymfoblastic leukemia in the Western European [15] and Brazilian studies [30]. Furthermore, the frequency of TS genotypes in the patients with leukemias United Kingdom [16, 29] did not show any significant difference compared to the controls.

The MTR $2756 A>G$ genotypes analysis show a significantly lower frequency of MTR 2756 GG genotype in the group of patients with breast cancer (4\%) compared to the control group $(8 \%, \mathrm{P}<0.05)$.

The results of OR calculation indicate 2-fold increase in the breast cancer risk for people with the MTR 2756 AA genotype (OR=2.00, CI - $95 \%$ : 1.11 - 3.60). The $2756 \mathrm{GA}$ genotype difference between the group of patients with breast cancer and the control group was statistically significant $(0.29$ 
I. Dmytruk, H. Makukh, M. Thyrkus et al.

Table 4. Distribution of two genotypes combination of $M T H F R$ 677C $>$ T, MTR 2756 A > G, DNMT3B -149C > T, DNMT3B $-579 \mathrm{G}>\mathrm{T}$ and $T Y M S 3 R 2 \mathrm{R}, 3 \mathrm{R} \mathrm{G}>\mathrm{C}$ polymorphisms among the patients with different types of cancer compared to the control group.

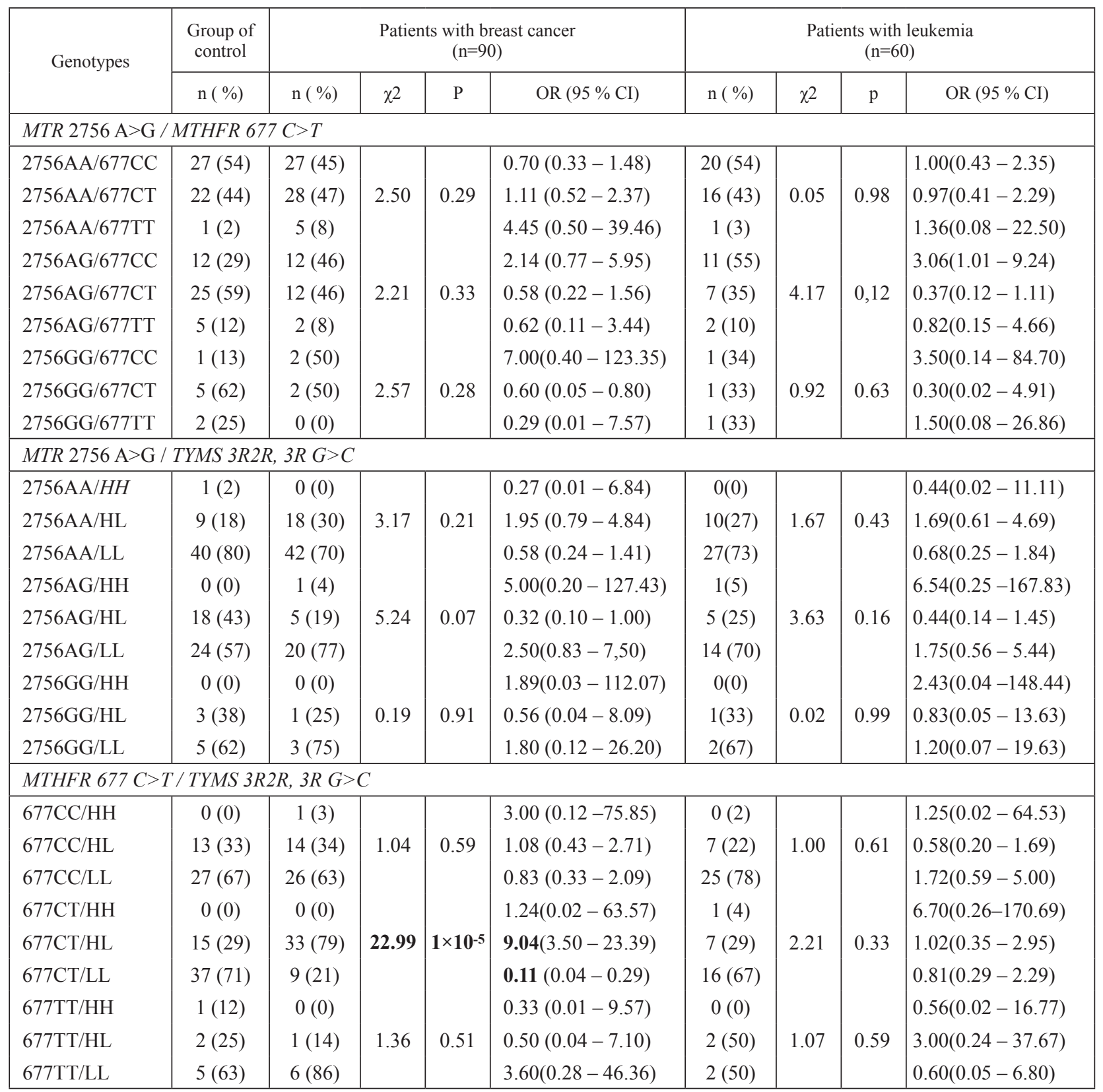

Note: $n$ - quantity of observation; $\boldsymbol{p}<\mathbf{0 . 0 5}$ - statistically significant difference; $\mathbf{O R}$ - statistically significant association between genotype and alleles polymorphism and cancer susceptibility; High (H) and low (L) TS expression genotypes based on TSER and TSER 3R G>C polymorphisms (high: 3RG/3RG, 3RG/3RC, 3RG/2R; low: 3RC/3RC, 3RC/2R, 2R/2R); HH-3RG3RG genotype; HL - 3RG2R, 3RG3RC genotypes; $L L-2 R 2 R$, 3RC2R, 3RC3RC genotypes 
The polymorphisms of genes involved in DNA methylation in patients with malignancies from West Ukraine

Table 5. Distribution of three genotypes combination of MTHFR 677C $>$ T, MTR 2756 A $>$ G, DNMT3B $-149 C>$ T, DNMT3B $-579 \mathrm{G}>\mathrm{T}$ and TYMS 3R2R, 3R G>C polymorphisms among the patients with different types of cancer compared to the control group.

\begin{tabular}{|c|c|c|c|c|c|c|c|c|c|}
\hline \multirow{2}{*}{ Genotypes } & \multirow{2}{*}{$\begin{array}{c}\begin{array}{c}\text { Group of } \\
\text { control }\end{array} \\
\mathrm{n}(\%) \\
\end{array}$} & \multicolumn{4}{|c|}{$\begin{array}{l}\text { Patients with breast cancer } \\
(\mathrm{n}=90)\end{array}$} & \multicolumn{4}{|c|}{$\begin{array}{l}\text { Patients with leukemia } \\
(\mathrm{n}=60)\end{array}$} \\
\hline & & $\mathrm{n}(\%)$ & $\chi^{2}$ & $P$ & OR $(95 \% \mathrm{CI})$ & $\mathrm{n}(\%)$ & $\chi^{2}$ & $\mathrm{p}$ & OR $(95 \% \mathrm{CI})$ \\
\hline \multicolumn{10}{|c|}{ MTHFR $677 C>T / M T R 2756 \mathrm{~A}>\mathrm{G} / T Y M S 3 R 2 R, 3 R G>C$} \\
\hline $\mathrm{CC} / \mathrm{AA} / \mathrm{HH}$ & $0(0)$ & $0(0)$ & & & $0.75(0.01-39.16)$ & $0(0)$ & & & $1.00(0.02-52.85)$ \\
\hline $\mathrm{CC} / \mathrm{AA} / \mathrm{HL}$ & $2(10)$ & $10(37)$ & 4.42 & 0.11 & $5.29(1.01-27.75)$ & $6(30)$ & 2.50 & 0.29 & $3.86(0.67-22.11)$ \\
\hline $\mathrm{CC} / \mathrm{AA} / \mathrm{LL}$ & $18(90)$ & $17(63)$ & & & $0.19(0.04-0.99)$ & $14(70)$ & & & $0.26(0.05-1.49)$ \\
\hline $\mathrm{CT} / \mathrm{AA} / \mathrm{HH}$ & $0(0)$ & $0(0)$ & & & $0.89(0.02-46.76)$ & $0(0)$ & & & $1.55(0.03-81.77)$ \\
\hline $\mathrm{CT} / \mathrm{AA} / \mathrm{HL}$ & $7(28)$ & $8(29)$ & 0.00 & 1.00 & $1.03(0.31-3.41)$ & $4(25)$ & 0.04 & 0,98 & $0.86(0.21-3.58)$ \\
\hline $\mathrm{CT} / \mathrm{AA} / \mathrm{LL}$ & $18(72)$ & $20(71)$ & & & $0.97(0.29-3.22)$ & $12(75)$ & & & $1.17(0.28-4.87)$ \\
\hline $\mathrm{TT} / \mathrm{AA} / \mathrm{HH}$ & $0(0)$ & $0(0)$ & & & $1.00(0.02-60.00)$ & $0(0)$ & & & $3.67(0.05-274.53)$ \\
\hline $\mathrm{TT} / \mathrm{AA} / \mathrm{HL}$ & $0(0)$ & $0(0)$ & 0.00 & 1.00 & $1.00(0.02-60.00)$ & $0(0)$ & 0.00 & 1.00 & $3.67(0.05-274.53)$ \\
\hline $\mathrm{TT} / \mathrm{AA} / \mathrm{LL}$ & $5(100)$ & $5(100)$ & & & $1.00(0.02-60.00)$ & $1(100)$ & & & $3.67(0.05-274.53)$ \\
\hline $\mathrm{CC} / \mathrm{AG} / \mathrm{HH}$ & $2(12)$ & $1(8)$ & & & $0.68(0.05-96.38)$ & $0(0)$ & & & $0.27(0.01-6.17)$ \\
\hline $\mathrm{CC} / \mathrm{AG} / \mathrm{HL}$ & $12(70)$ & $3(25)$ & 7.36 & 0.03 & $0.14(0.03-0.74)$ & $1(9)$ & 14.45 & $7 \times 10^{-4}$ & $0.04(0.00-0.42)$ \\
\hline $\mathrm{CC} / \mathrm{AG} / \mathrm{LL}$ & $3(18)$ & $8(67)$ & & & $\mathbf{9 . 3 3}(1.65-52.69)$ & $10(91)$ & & & 46.6(4.22-516.64) \\
\hline $\mathrm{CT} / \mathrm{AG} / \mathrm{HH}$ & $0(0)$ & $0(0)$ & & & $1.80(0.03-96.38)$ & $1(25)$ & & & $19.29(0.65-523.86)$ \\
\hline $\mathrm{CT} / \mathrm{AG} / \mathrm{HL}$ & $7(32)$ & $1(8)$ & 2.38 & 0.30 & $0.19(0.02-1.82)$ & $0(0)$ & 6.80 & 0.03 & $0.23(0.01-4.84)$ \\
\hline $\mathrm{CT} / \mathrm{AG} / \mathrm{LL}$ & $15(68)$ & $11(92)$ & & & $5.13(0.55-47,98)$ & $3(75)$ & & & $1.40(0.12-15.97)$ \\
\hline TT/AG/HH & $0(0)$ & $0(0)$ & & & $1.89(0.03-112.07)$ & $0(0)$ & & & $2.43(0.04-148.44)$ \\
\hline $\mathrm{TT} / \mathrm{AG} / \mathrm{HL}$ & $3(38)$ & $1(25)$ & 0.19 & 0.91 & $0.56(0.04-8.09)$ & $1(33)$ & 0.02 & 0.99 & $0.83(0.05-13.63)$ \\
\hline $\mathrm{TT} / \mathrm{AG} / \mathrm{LL}$ & $5(62)$ & $3(75)$ & & & $1.80(0.12-26.20)$ & $2(67)$ & & & $1.20(0.07-19.63)$ \\
\hline $\mathrm{CC} / \mathrm{GG} / \mathrm{HH}$ & $0(0)$ & $0(3)$ & & & $0.71(0.01-49.71)$ & $0(2)$ & & & $1.67(0.02-137.36)$ \\
\hline $\mathrm{CC} / \mathrm{GG} / \mathrm{HL}$ & $1(50)$ & $1(33)$ & 0.14 & 0.93 & $0.50(0.01-19.56)$ & $0(0)$ & 0.75 & 0.69 & $0.33(0.01-16.80)$ \\
\hline $\mathrm{CC} / \mathrm{GG} / \mathrm{LL}$ & $2(50)$ & $1(67)$ & & & $2.00(0.05-78.25)$ & $1(100)$ & & & $3.00(0.06-151.20)$ \\
\hline $\mathrm{CT} / \mathrm{GG} / \mathrm{HH}$ & $0(0)$ & $0(0)$ & & & $2.20(0.03-146.04)$ & $0(0)$ & & & $3.67(0.05-274.53)$ \\
\hline $\mathrm{CT} / \mathrm{GG} / \mathrm{HL}$ & $0(0)$ & $1(50)$ & 2.92 & 0.09 & $11.00(0.28-433.83)$ & $0(0)$ & 0.00 & 1.00 & $3.67(0.05-274.53)$ \\
\hline $\mathrm{CT} / \mathrm{GG} / \mathrm{LL}$ & $5(100)$ & $1(50)$ & & & $0.09(0.00-3.59)$ & $1(100)$ & & & $3.67(0.05-274.53)$ \\
\hline $\mathrm{TT} / \mathrm{GG} / \mathrm{HH}$ & $0(0)$ & $0(0)$ & & & & $0(0)$ & & & \\
\hline TT/GG/HL & $0(0)$ & $0(0)$ & - & - & & $1(100)$ & & - & \\
\hline TT/GG/LL & $0(0)$ & $0(0)$ & & & - & $0(0)$ & & & - \\
\hline
\end{tabular}

Note: $n$ - quantity of observation; $\boldsymbol{p}<\mathbf{0 . 0 5}$ - statistically significant difference; $\mathbf{O R}$ - statistically significant association between genotype and alleles polymorphism and cancer susceptibility; High $(H)$ and low $(L)$ TS expression genotypes based on TSER and TSER $3 R G>C$ polymorphisms (high: $3 R G / 3 R G, 3 R G / 3 R C, 3 R G / 2 R$; low: $3 R C / 3 R C, 3 R C / 2 R, 2 R / 2 R$ ); $H H$ - 3RG3RG genotype; $H L-3 R G 2 R, 3 R G 3 R C$ genotypes; $L L-2 R 2 R$, $3 R C 2 R, 3 R C 3 R C$ genotypes

vs. 0.42; $\mathrm{P}<0.05)$. The frequency of the $2756 \mathrm{G}$ alelle among the patients with breast cancer $(0.19)$ was statistically significant compared to the control $(0.29$; $\mathrm{P}<0.05)$. The possibility of breast cancer develop- ment increases by 1.75 times $(\mathrm{OR}=1.75$, CI $95 \%: 1.08-2.84$ ) in the presence of at least one copy of the $2756 \mathrm{~A}$ allele. The association with breast cancer risk was found for the Brazilian [14], Indian 
[31] women carrying the MTR A2756G polymorphic allele. It was revealed by meta-analysis that the MTR A2756G polymorphism may contribute to the susceptibility to breast cancer among Europeans [32]. However, in many studies the scientists cannot find a significant association of the MTR A2756G polymorphisms with the breast cancer risk [33].

The distribution of the MTR $2756 A G$ genotypes and allele did not show significant difference in the control group and the group of patients with leukemia. The frequency of low enzyme activity $2756 \mathrm{GG}$ genotype in the case group consists $5 \%$ and in the control group $8 \%$. In the study on British population also was not found significant difference in the susceptibility to acute leukemia for the MTR 2756AG polymorphism [16]. The association of this polymorphism has been reinforced in a meta-analysis, being the $2756 \mathrm{AA}$ genotype reduced risk of developing childhood acute lymphoblastic leukemia [34].

In our research we also analyzed the distribution of different genotypes combination in group of patient with breast cancer, leukemia and control group. In fact, we compared combination of two and three genotypes of MTHFR $677 \mathrm{C}>\mathrm{T}$, MTR $2756 \mathrm{~A}>\mathrm{G}$, DNMT3B -149C $>$ T, DNMT3B -579 G $>$ T and TYMS 3R2R, 3R G $>$ C polymorphisms (Table 4, Table 5).

Our findings show statistically significant difference in distribution of MTHFR $677677 \mathrm{C}>\mathrm{T} /$ TYMS 3R2R, 3R G $>$ C polymorphic loci genotypes combination in control group and group of women with breast cancer. The frequency of MTHFR $677 \mathrm{CT} /$ TYMS LL genotypes was significant higher in control group (71\%) compared to group of patient with breast cancer $(21 \%)$, therefore, the frequency of MTHFR 677CT/ TYMS HL genotypes was significant higher in observed group with breast cancer (79\%) compared to control $(29 \%)$. The OR calculation show that carriers of MTHFR 677CT/ TYMS LL genotypes has reduced risk of breast cancer $(\mathrm{OR}=0.11$, CI $95 \%$ : $0.04-0.29$ ), and the carriers of MTHFR $677 \mathrm{CT} /$ TYMS HL genotypes, on the contrary, has increased breast cancer risk $(\mathrm{OR}=9.04, \mathrm{CI} 95 \%$ : $3.50-23.39)$.

The analysis of three genotype combination shown that carriers of MTHFR $677 \mathrm{CC} / \mathrm{MTR}$
2756AG/ TYMS LL genotypes were over represented in cases (breast cancer group - $67 \%$, group of leukemia - $91 \%$ ) compared to controls $(18 \%)$.The presence of the MTHFR $677 \mathrm{CC} / \mathrm{MTR} 2756 \mathrm{AG} /$ TYMS LL genotypes was associated with 9.33-fold risk of breast cancer and 46.6-fold risk of leukemia. In group of patient with leukemia was established higher frequency of MTHFR 677CT/ MTR 2756AG/ TYMS HH (0 \%) and MTHFR 677CT/ MTR 2756AG/ TYMS LL (68\%) genotypes combination compared to control group (25\% and $75 \%$, respectively). These differences between the cases and controls were statistically significant $(\mathrm{p} \leq 0.05)$.

In summary, we found that different genotypes combination of MTHFR, MTR and TYMS genes polymorphisms in the West Ukrainian population could mediate the risk of breast cancer and leukaemia via effects on pools of methyl groups needed for genes methylation. The reasons for contrary results obtained in our research and other studies remain ambiguous and might be attributed to the differences in ethnic backgrounds and the selection of the population studied, differences in sample sizes, and geneenvironment interactions. It is reasonable to repeat a comprehensive research in the whole country for clarifying a role of the genes involved in the DNA methylation process in cancer susceptibility.

\section{Conclusion}

Our findings show that West Ukrainian residents carrying at least one MTR 2756A allele have a significantly increased risk of breast cancer. Also, we find out, that susceptibility to breast cancer and leukaemia in West Ukrainians relate to the combination of few genotypes: MTHFR 677CC/ MTR 2756AG/ TYMS $\mathrm{LL}$ - increased the risk of breast cancer and leukaemia, 677CT/ TYMS HL - raise the risk of breast cancer and the presence of MTHFR 677CT/ TYMS LL genotypes acts as a protector factor for breast cancer development.

\section{Funding}

Expenses were partially covered by West Ukrainian Biomedical Research Centre (WUBMRC) grant. 
The polymorphisms of genes involved in DNA methylation in patients with malignancies from West Ukraine

\section{REFERENCE}

1. Herman JG, Baylin SB. Gene silencing in cancer in association with promoter hypermethylation. $N$ Engl $J$ Med. 2003;349(21):2042-54.

2. Choi $S W$, Mason JB. Folate and carcinogenesis: an integrated scheme. J Nutr. 2000;130(2):129-32.

3. Robertson $K D$. DNA methylation, methyltransferases, and cancer. Oncogene. 2001;20(24):3139-55

4. de Vogel $S$, Wouters $K A$, Gottschalk RW, van Schooten FJ, de Goeij AF, de Brü̈ne AP, Goldbohm RA, van den Brandt PA, Weijenberg $M P$, van Engeland $M$. Genetic variants of methyl metabolizing enzymes and epigenetic regulators: associations with promoter $\mathrm{CpG}$ island hypermethylation in colorectal cancer. Cancer Epidemiol Biomarkers Prev. 2009;18(11):3086-96.

5. Weisberg I, Tran P, Christensen B, Sibani S, Rozen R. A second genetic polymorphism in methylenetetrahydrofolate reductase (MTHFR) associated with decreased enzyme activity. Mol Genet Metab. 1998;64(3):169-72.

6. Frosst P, Blom HJ, Milos R, Goyette P, Sheppard CA, Matthews RG, Boers GJ, den Heijer M, Kluijtmans LA, van den Heuvel $L P$, et al. A candidate genetic risk factor for vascular disease: a common mutation in methylenetetrahydrofolate reductase. Nat Genet. 1995;10(1):111-3.

7. Goode EL, Potter JD, Bigler J, Ulrich CM. Methionine synthase D919G polymorphism, folate metabolism, and colorectal adenoma risk. Cancer Epidemiol Biomarkers Prev. 2004;13(1):157-62.

8. Hubner RA, Muir KR, Liu JF, Sellick GS, Logan RF, Grainge M, Armitage N, Chau I, Houlston RS. Folate metabolism polymorphisms influence risk of colorectal adenoma recurrence. Cancer Epidemiol Biomarkers Prev. 2006;15(9):1607-13.

9. Pullarkat ST, Stoehlmacher J, Ghaderi V, Xiong YP, Ingles SA, Sherrod A, Warren R, Tsao-Wei D, Groshen $S$, Lenz HJ. Thymidylate synthase gene polymorphism determines response and toxicity of 5-FU chemotherapy. Pharmacogenomics $J .2001 ; 1(1): 65-70$.

10. Hubner RA, Muir KR, Liu JF, Sellick GS, Logan RF, Grainge M, Armitage N, Chau I, Houlston RS. Folate metabolism polymorphisms influence risk of colorectal adenoma recurrence. Cancer Epidemiol Biomarkers Prev. 2006;15(9):1607-13.

11. Takehara A, Kawakami K, Ohta N, Oyama K, Ota Y, Oda M, Watanabe $G$. Prognostic significance of the polymorphisms in thymidylate synthase and methylenetetrahydrofolate reductase gene in lung cancer. Anticancer Res. 2005;25(6C):4455-61.

12. Hosseini $M$. Role of polymorphism of methyltetrahydrofolate-homocysteine methyltransferase (MTR) A2756G and breast cancer risk. Pol J Pathol. 2013;64(3):191-5.

13. Sharp L, Little J, Schofield AC, Pavlidou E, Cotton SC, Miedzybrodzka Z, Baird JO, Haites NE, Heys SD, Grubb DA. Folate and breast cancer: the role of polymorphisms in methylenetetrahydrofolate reductase (MTHFR). Cancer Lett. 2002;181(1):65-71.
14. de Cássia Carvalho Barbosa R, da Costa DM, Cordeiro DE, Vieira AP, Rabenhorst SH. Interaction of MTHFR C677T and A1298C, and MTR A2756G gene polymorphisms in breast cancer risk in a population in Northeast Brazil. Anticancer Res. 2012;32(11):4805-11.

15. Koppen IJ, Hermans FJ, Kaspers GJ. Folate related gene polymorphisms and susceptibility to develop childhood acute lymphoblastic leukaemia. Br J Haematol. 2010; 148(1):3-14.

16. Skibola CF, Smith MT, Hubbard A, Shane B, Roberts AC, Law GR, Rollinson S, Roman E, Cartwright RA, Morgan GJ. Polymorphisms in the thymidylate synthase and serine hydroxymethyltransferase genes and risk of adult acute lymphocytic leukemia. Blood. 2002;99(10):3786-91.

17. Lauten M, Asgedom G, Welte K, Schrappe M, Stanulla M. Thymidylate synthase gene polymorphism and its association with relapse in childhood B-cell precursor acute lymphoblastic leukemia. Haematologica. 2003;88(3):353-4.

18. * Makukh HV, Zastavna DV, Tyrkus MJ, et all. The manner of DNA extraction from the peripheral blood leukocytes Appl. №u200801896; Filed febr.14.2008. Date of patent aip.25.2008.

19. Oh D, Kim NK, Jang MJ, Kim HC, Lee JH, Lee JA, Ahn MJ, Kim CS, Kim HS, Park S, Chio HS, Min YH; HOGS Investigators. Association of the 5,10-methylenetetrahydrofolate reductase (MTHFR C677T and A1298C) polymorphisms in Korean patients with adult acute lymphoblastic leukemia. Anticancer Res. 2007;27(5A):3419-24.

20. Thirumaran RK, Gast A, Flohr T, Burwinkel B, Bartram C, Hemminki K, Kumar R. MTHFR genetic polymorphisms and susceptibility to childhood acute lymphoblastic leukemia. Blood. 2005;106(7):2590-1.

21. de Jonge R, Tissing WJ, Hooijberg JH, Jansen G, Kaspers GJ, Lindemans J, Peters GJ, Pieters R. Polymorphisms in folate-related genes and risk of pediatric acute lymphoblastic leukemia. Blood. 2009;113(10):2284-9.

22. Rai $V$. The methylenetetrahydrofolate reductase $\mathrm{C} 677 \mathrm{~T}$ polymorphism and breast cancer risk in Asian populations. Asian Pac J Cancer Prev. 2014;15(14):5853-60.

23. Pooja S, Carlus J, Sekhar D, Francis A, Gupta N, Konwar R, Kumar S, Kumar S, Thangaraj K, Rajender S. MTHFR $677 \mathrm{C}>\mathrm{T}$ polymorphism and the risk of breast cancer: evidence from an original study and pooled data for 28031 cases and 31880 controls. PLoS One. 2015;10(3):e0120654.

24. Försti A, Angelini S, Festa F, Sanyal S, Zhang Z, Grzybowska E, Pamula J, Pekala W, Zientek H, Hemminki K, Kumar $R$. Single nucleotide polymorphisms in breast cancer. Oncol Rep. 2004;11(4):917-22.

25. Kalemi TG, Lambropoulos AF, Gueorguiev M, Chrisafi S, Papazisis KT, Kotsis A. The association of p53 mutations and p53 codon 72, Her 2 codon 655 and MTHFR C677T polymorphisms with breast cancer in Northern Greece. Cancer Lett. 2005;222(1):57-65. 
26. Kawakami K, Watanabe G. Identification and functional analysis of single nucleotide polymorphism in the tandem repeat sequence of thymidylate synthase gene. Cancer Res. 2003;63(18):6004-7.

27. Henríquez-Hernández LA, Murias-Rosales A, Hernández González A, Cabrera De León A, Díaz-Chico BN, Mori De Santiago M, Fernández Pérez L. Gene polymorphisms in TYMS, MTHFR, p53 and MDR1 as risk factors for breast cancer: a case-control study. Oncol Rep. 2009;22(6):1425-33.

28. Quintero-Ramos A, Gutiérrez-Rubio SA, Del Toro-Arreola A, Franco-Topete RA, Oceguera-Villanueva A, JiménezPérez LM, Castro-Cervantes JM, Barragán-Ruiz A, Vázquez-Camacho JG, Daneri-Navarro A. Association between polymorphisms in the thymidylate synthase gene and risk of breast cancer in a Mexican population. Genet Mol Res. 2014;13(4):8749-56.

29. Lightfoot TJ, Johnston WT, Painter D, Simpson J, Roman E, Skibola CF, Smith MT, Allan JM, Taylor GM; United Kingdom Childhood Cancer Study. Genetic variation in the folate metabolic pathway and risk of childhood leukemia. Blood. 2010;115(19):3923-9.

30. Canalle R, Silveira VS, Scrideli CA, Queiroz RG, Lopes LF, Tone $L G$. Impact of thymidylate synthase promoter and DNA repair gene polymorphisms on susceptibility to childhood acute lymphoblastic leukemia. Leuk Lymphoma. 2011; 52(6):1118-26.

31. Naushad SM, Pavani A, Rupasree Y, Divyya S, Deepti S, Digumarti RR, Gottumukkala SR, Prayaga A, Kutala VK. Association of aberrations in one-carbon metabolism with molecular phenotype and grade of breast cancer. Mol Carcinog. 2012;51 Suppl 1:E32-41.

32. Lu M, Wang F, Qiu J. Methionine synthase A2756G polymorphism and breast cancer risk: a meta-analysis involving 18,953 subjects. Breast Cancer Res Treat. 2010;123(1):213-7.

33. Weiner AS, Boyarskikh UA, Voronina EN, Selezneva IA, Sinkina TV, Lazarev AF, Petrova VD, Filipenko ML. Polymorphisms in the folate-metabolizing genes MTR, MTRR, and CBS and breast cancer risk. Cancer Epidemiol. 2012;36(2):e95-e100.

34. Xia J, Wang Y, Zhang H, Hu Y. Association between MTR A2756G polymorphism and childhood acute lymphoblastic leukemia: a meta-analysis. Leuk Lymphoma. 2014;55(6): 1388-93.

\section{Поліморфізм генів задіяних в процесах метилування ДНК у паціснтів $з$ онкологічними захворюваннями з західного регіону України \\ I. М. Дмитрук, Г. В. Макух, М. Я. Тиркус, Н. І. Кіцера}

Мета. Визначити потенційну роль поліморфізму генів MTHFR, $M T R$ та TYMS в розвитку раку молочної залози і лейкемії серед жителів Західної України. Методи. Проведено генотипування поліморфних локусів MTHFR $677 C>T$, MTR 2756A>G, TYMS $3 R 2 R$ та $T Y M S 3 R G>C$ у 60 пацієнтів з лейкемією, 90 пацієнтів
3 раком молочної залози та в 100 осіб контрольної групи. Молекулярно-генетичний аналіз проводили за допомогою полімеразної ланцюгової реакції та аналізу поліморфізму довжин рестрикційних фрагментів. Статистичний аналіз проведений шляхом розрахунку $\chi$-квадрат та обчислення коефіцієнту відношення шансів (OR). Результати. Вірогідних відмінностей у розподілі генотипів та алелей щодо поліморфних локусів генів $M T H F R$ та TYMS не встановлено. Встановлено вірогідно вищу частоту генотипу MTR $2756 A A$ у групі осіб з раком молочної залози в порівнянні 3 контролем $(0,67$ та $0,50, \mathrm{p}=0,02)$, у групі осіб з лейкемією показники не відрізнялися відносно контролю. Вищий ризик розвитку раку молочної залози асоційований з генотипом $A A(\mathrm{OR}=2,00$, CI-95 \%:1.11-3.60) та $A$ алелю $(\mathrm{OR}=$ 1,75, CI-95 \%:1,08-2,84) поліморфного локусу $M T R 2756 A>G$. Висновки: Встановлено, що наявність однієї копії алеля $M T R$ $2756 A$ може підвищувати ризик виникнення раку молочної залози у жителів Західної України.

Кл юч о в і с л о в а: метилування, поліморфізм, ген, лейкемія, рак молочної залози

\section{Полиморфизм генов, задействованных в процессах метилирования ДНК у пациентов с онкологическими заболеваниями из западного региона Украины}

\section{И. М. Дмитрук, Г. В. Макух, М. Я. Тиркус, Н. И. Кицера}

Цель. Определить потенциальную роль полиморфизма генов $M T H F R, M T R$ и TYMS в развитии рака молочной железы и лейкемии среди жителей Западной Украины. Методы. Проведено генотипирование полиморфных локусов MTHFR $677 \mathrm{C}>\mathrm{T}$, $M T R 2756 A>G$, TYMS 3R2R и TYMS $3 R G>C$ у 60 пациентов с лейкемией, 90 пациентов с раком молочной железы и у 100 человек контрольной группы. Молекулярно-генетический анализ проводили с помощью полимеразной цепной реакции и анализа полиморфизма длин рестрикционных фрагментов. Статистический анализ проведен путем расчета $\chi$-квадрат и вычисления коэффициента отношения шансов (OR). Результаты. Достоверных различий в распределении генотипов и аллелей полиморфных локусов генов MTHFR и TYMS не установлено. Установлено достоверно высокую частоту генотипа $M T R 2756 A A$ в группе лиц с раком молочной железы по сравнению с контролем $(0,67$ и $0,50, \mathrm{p}=0,02)$, в группе лиц с лейкемией показатели не отличалась относительно контроля. Риск развития рака молочной железы, ассоциированный с генотипом $\mathrm{AA}(\mathrm{OR}=2,00, \mathrm{CI}-95 \%: 1.11-3.60)$ и А аллея $(\mathrm{OR}=1,75$, CI-95 \%:1,08-2,84) полиморфного локуса MTR 2756 A>G. Выводы установлено, что наличие одной копии аллеля MTR 2756 А может повышать риск возникновения рака молочной железы у жителей Западной Украины.

Кл юч е в ы е сл о в а: метилирование, полиморфизм, ген, лейкемия, рак молочной железы 